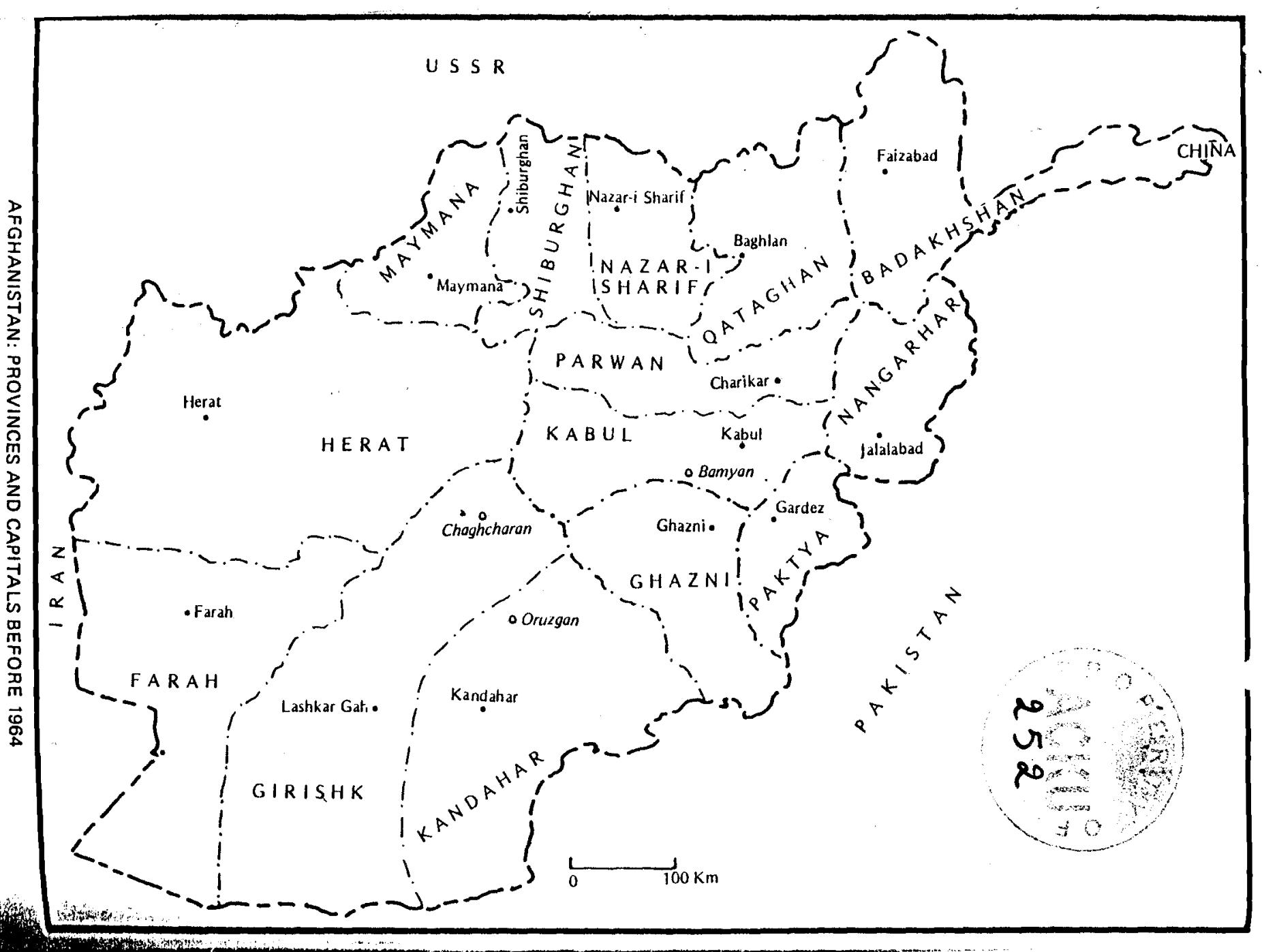




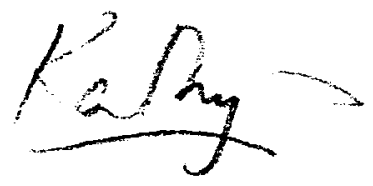

Chapter 13

\title{
CAUSES AND CONSEQUENCES OF THE ABOLITION OF BRIDEPRICE IN AFGHANISTAN
}

\author{
Nancy Tapper
}

In 1978 the government of Nur M. Taraki, President of the Revolutionary Council in Afghanistan, initiated a wide-ranging program of change and development. Along with land reform and other measures to wrest power from traditional leaders in Afghan society, the government promulgated Decree No. 7, which aimed at fundamental change in the institution of marriage. A prime concern of the decree, which also motivated other reforms of the Taraki government, was to reduce material indebtedness throughout the country; it was also meant to ensure the equal rights of women with men.* In this chapter I shall argue that if reforms such as those embodied in Decree No. 7 were implemented, they would be unlikely to change either the levels of indebtedness or the status of women in any direct way. Rather they would be likely to alter the whole system of economic goals and values throughout much of rural Afghanistan and perhaps in addition lead to fundamental changes in the nature of ethnic relations in the countryside. It is not difficult to suggest how legislative changes might disrupt such traditional systems, but what form a succeeding structure might take depends on the outcome of the national political struggles in general. In any case, although such proposed reforms, casting the issues of poverty and women's status into a basically First World perspective, may be seen

"Thus in a speech on 4 November 1978 President Taraki said that it was "through the issuance of decrees no. 6 and 7, the hard-working peasants were freed from the bonds of oppressors and money-lenders, etc. ending the sale of girls for good as hereafter nobody would be entitled to sell any girl or woman in this country" (Afghanistan, MIC, DRA Annual 1979:216). 
as a radical improvement from the legislators' point of view, this perspective has many critics in the Third World and elsewhere.

I shall begin with an overview on legal reforms concerning marriage; present a brief discussion of an anthropological perspective on marriage payments, in which I shall offer ethnographic evidence to suggest something of the character and scale of the possible consequences of the implementation of a marriage reform; and conclude with an analysis of ethnicity and marriage in Afghanistan.

\section{LEGAL REFORMS AND THE STATUS OF WOMEN}

The first two articles in Decree No. 7 forbid (respectively) the exchange of a woman in marriage for cash or kind and the payment of other prestations customarily due from a bridegroom on festive occasions; the third article sets an upper limit of 300 afs. on the mahr, a payment due from groom to bride which is an essential part of the formal Islamic marriage contract.* In addition, the legislation aims to change marriage customs so as to give young women and men independence of their marriage guardians. Thus (albeit somewhat ambiguously) the ages of first engagement and marriage are raised to sixteen for women and eighteen for men. The decree further stipulates that no one, including widows, can be compelled to marry against his or her will; it carries the implication that no one can be prevented from marrying if he or she so desires. The penalties instituted to uphold these measures include the forfeiture of any illegally paid brideprice or other marriage prestations and a prison sentence of between six months and three years (Anis, 25 Mizan 1357 A.H. [1978] ; Afghanistan, MIC, DRA Annual 1979:86-87, 216). ${ }^{\dagger}$

*Taraki explained that "we are always taking into consideration and respect the basic principles of Islam. Therefore, we devised that an equivalent of the sum to be paid in advance by the husband to his wife upon the nuptial amounting to 10 'dirhams' [traditional ritual payment] according to 'shari'at' [Islamic canon law] be converted into local currency which is afs. 300 . We also decided that marriageable boys and girls should freely choose their future spouses in line with the rules of shari'at" (Afghanistan, MIC, DRA Annual 1979:216).

'See the interesting discussion of earlier marriage reform in Afghanistan, the political background to Decree No. 7, and some of its implications for the position of Afghan women in N. Dupree (1981:1, 10-12). 
Implicit in the thinking behind the decree (and most other reforms of the institution of marriage elsewhere) is the assumption that brideprice payments and other marriage gifts directly cause general indebtedness on the one hand and an inferior status for women vis-a-vis men on the other. If the causality of these relations is taken for granted, any examination of their exact nature is inhibited. Such thinking itself becomes a political dogma; its proponents ignore its historical origins, and, because the dogma is couched in ideal/legalistic terms, they pay little attention to the social practices it attacks. For instance, such thinking directs attention away from the way status inequality generally and thus social and material poverty (as opposed to simple economic indebtedness) are actually created and perpetuated through the institution of marriage as a whole; similarly it leaves unexplored the relation between marriage and the social and cultural construction of gender roles.

The two aims of Decree No. 7-to reduce material indebtedness associated with marriage and to improve the status of women-are parallel to and historically connected with legislative reforms of the institution of marriage which have occurred throughout the world, not least in the Americas and Europe, over the last one hundred years or so. Clearly the impetus for such reforms derived from changes in the roles of women and the institution of marriage in Western industrial society and the ideological shifts which these entailed; the changes included an increasing "domestication" of women, their marginalization from the modern economy, and a decline in the importance of marriage as an institution articulating values and activities relevant in many areas of social life. However, the changes which led to reform measures in the West did not necessarily occur in societies where the institution of marriage may have continued to occupy a fundamentally different and more important role in articulating persons, resources, and information. But with the expansion of colonial empires and increasing Western ideological dominance, the particular socioeconomic context of marriage reforms in the West was forgotten, and the value system of which they were a part came to be represented as universally valid. The situation described by Sayigh is relevant throughout the Muslim Middle East (as well as elsewhere): by the end of the nineteenth century, the institution of marriage and the status of women in Islamic countries were treated as indicators of the backwardness of Islamic cultures, which 
might "catch up with the West" only through a process of social evolution and imitative change (1981:263).

Some of the better known examples of the universalizing of the Western value system were marriage reforms introduced into African societies in the 1930s, when colonial administrators particularly attacked brideprices paid in cattle (see Mair 1971:195-96), and certain forms of marriage- such as exchange marriage among the Tiv of West Africa-were prohibited both because they offered women little say in marriage arrangements and because of the web of indebtedness they created (Bohannan 1967). Furthermore, Christian missionary activity throughout the world has usually been based on assumptions about the absolute value of Western institutions. And marriage reforms similar to those in Africa have occurred elsewhere, though in a less direct fashion; see, for example, Croll's discussion of contemporary China (1981).

In Afghanistan previous rulers had introduced reforms relating to marriage and women's status; their aim was to transform Afghanistan into a "modern" society. In this respect Decree No. 7 has much in common with marriage reforms from the time of Amir "Abdur Rahman Khan (1880-1901). Writing of Amanullah Khan's Family Code of 1921, Gregorian notes the following:

Some token efforts at reform had been made in this area by Abdur Rahman and Habibullah. but none of their measures were as great in scope or as earnestly applied as those of Amanullah. Child marriage and intermarriage between close kin were outlawed as contrary to Islamic principles. In the new code Amanullah reiterated Abdur Rahman's ruling that a widow was to be free of the domination of her husband's family, followed his father's example and placed tight restrictions on wedding expenses, including dowries, and granted wives the right to appeal to the courts if their husbands did not adhere to Quranic tenets regarding marriage. One source reports that in the fall of 1924, Afghan girls were given the right to choose their husbands, a measure that incensed the traditionalist elements (1969:243-44).

Reforms after Amanullah were similar to his in substance. Louis Dupree notes that a 1950 law banning "ostentatious life-crises ceremonies prohibits many of the expensive aspects of birth, circum- 
cision, marriage and burial rituals" (1973:209), and Knabe gives details of how the Marriage Law of 1971 was a further attempt by lawmakers to curb the indebtedness which arises from the costs of marriage (1977a:164), which "are a burden for Afghan society as a whole" (1977a:149).

Kemali has examined in detail the history of marriage reform in Afghanistan:

To date the areas conventionally covered by marriage reform [problems of excessive expenditure in marriage ceremonies, child marriage, polygamy, and divorce] are governed by the traditional Hanafi law which, on the whole has remained in its medieval form in Afghanistan. The existent statutory legislation which has been added to the Hanafi law, has introduced no substantial change to the Hanafi traditional doctrines (1976:i).

Only in July 1973, when the conservative nature of the Afghan constitution was one of the issues behind the coup d'etat which established Muhammad Daoud's Afghan Republic, did there seem some chance of promulgating more substantial marriage reforms coupled with legal sanctions. Kemali, in response to what he sees as the "social evils emanating from excessive expenditure in marriage" (1976:47), outlines directions the reforms might take to correct the consequences of traditional practices. The continuity is clearbetween his arguments in favor of marriage reform, those of earlier reformers, and those of the draftees of Decree No. 7: all derive from Western models of social production and reproduction; moreover, they contain a distinct Pashtun ethnic bias in their understanding of the traditional institutions of marriage in Afghanistan. Kemali notes the following:

Excessive expenditure in marriage undermines the human dignity of women as it tends to render them into a kind of property of the husband or his family. [It] weakens the financial status of the family and tends to bring or worsen poverty. [It] tends to render the adults highly dependent on family resources; this in turn weakens their position in regard to the exercise of their right of consent in marriage as well as their freedom of choice of a life partner. Dependence of the youth on the family resources is enormous even without the stimulus of this additional factor. Marriage 
becomes largely dependent on the possession of financial means; this leads to intolerable discriminations against the poor. Excessive expenditure in marriage deprives many of the right to marry (e.g. many women); it also leads to late marriages, and often brings about a wide disparity of age between the spouses. Excessive expenditure in marriage constitutes a source of embitterment and conflict during the course of marital life.... Costly marriages contribute to the continuance of the tradition-bound society and tend to slow down the process of reform... The practice is selfperpetuating (1976:47-48).

In Afghanistan, as elsewhere in the Muslim Middle East, the legal code relating to marriage and the family is based directly on the Shari'a or canon law of Islam, and reforms in this area have typically provoked extreme reactions, explicitly in the defense of Islamic principles. However, it would seem that the relation between reform legislation and Islamic fundamentalism actually works the other way around. The strength of the reaction clearly depends on the importance of the institutions of marriage and the family in the regulation of daily living and the extent to which they are threatened. Since many Muslims see few discrepancies among customary practices, social identity within a community, and formal Islam, the last can become a source of ideological unity which may be used to defend a traditional social structure.

"Islamic" reaction to marriage and family reforms has often idealized the position of women by taking an extreme legalistic view of Islamic family law. Arguments between political and social progressives and reactionaries crystallize around the issue of "women's status" (a concept which itself conceals a variety of biases which derive from Western male models of gender). Men and women who see themselves as educated and modern can justify attempts to change the customs of those they label tradition-bound and ignorant in terms of raising the status of women. Modernization-implicitly meaning the growth of technological skills, material wealth, and social complexity on a Western model-becomes for the progressive, educated elite an unambiguous goal, and in an area such as the reform of marriage, a direct link is assumed between the nature of the traditional institution and poverty and the assumption left unexamined. In Afghanistan, even in the context of the Saur 
Revolution, such complicated associations have continued to be evident in attempts to propound legal reforms which could reconcile Islamic principles with progressive politics and the goal of modernization.*

\section{AN ANTHROPOLOGICAL PERSPECTIVE ON MARRIAGE PAYMENTS}

It has long been accepted by anthropologists that marriage prestations in any society do not admit to a simple economic or utilitarian interpretation because, as Comaroff points out, "their utilitarian quality is [itself] a culturally constituted variable" (1980: 41). "Moreover, the way in which actors experience and construe transactions does not itself explain why those transactions occur, or how they relate to an ordered set of values in any socio-cultural sysstem" (11). Comaroff offers a general criticism of previous studies of marriage prestations; his main objection is the "tendency ... to make a functional distinction [between marriage and marriage prestations] in which marriage is seen as structurally prior, and prestations largely as its institutionalized mode of facilitation (35-36). He argues that this misses the point that where marriage payments exist, "they represent a critical element in the symbolic order with reference to which unions are classified and invested with social currency" (36) and that "the meaning of marriage prestations, given their semantic relationship to marriage, depends in large measure upon the location of the latter in any constitutive order" (39).

Such a perspective on brideprice and marriage gifts is particularly important in the case of marriage systems such as those found in rural communities throughout Afghanistan, in which the making of marriages is the central focus of most economic and political activity and the principal means by which status is expressed and validated. This is particularly the case of the marriage system among the Durrani Pashtuns in north-central Afghanistan, among whom (I have argued) "marriage prestations and the transfer of women between households must be seen as part of the wider system of exchange and control of all productive and reproductive resources" (N. Tapper $1979 ; 1981: 387$ ff.).

"In this context see especially N. Dupree (1981). 
ETHNOGRAPHIC EVIDENCE ON THE CONSEQUENCES OF MARRIAGE REFORM

To illustrate, in terms of one Afghan community, the probable short- and longer-term impact of marriage reforms such as Decree No. 7 on communities in rural Afghanistan, I draw on ethnographic material collected by Richard Tapper and myself in 1970-72.* The community of Ishaqzai Durrani-numbered some two hundred hou seholds living in villages in the Saripul district of Jawzjan province, where they operated a dual economy based on the ownership of extensive irrigated farmland and flocks which were taken to summer pastures in the Hazarajat.

I argue that for these Durrani the whole structure of social and material poverty as well as the spectrum of relations between the sexes is articulated through the institution of marriage. The heaviest expenses any household has to bear are concerned with marriage. In other words, production is directed largely toward reproductiontoward acquiring wives who will produce sons who will produce labor and political support in defense of productive and reproductive resources, especially land and women. The expense of marriage is considerable among the Durrani. The average value of brideprices in 1971-72 (paid in cash, animals, and other goods) was 65,000 afs., then about $\$ 800$-several times an average household's annual income. It is important to note that brideprices vary much less between rich and poor Durrani than household wealth or income, so that marriage is much more difficult for the poor than for the rich. At the same time, the poor can aspire to the same kinds of marriages as the rich, and they sometimes compete for the same women.

The marriage arrangements made by a poorer household almost never result in direct indebtedness, but the choice of bride, the agreed brideprice, and the time taken to complete a marriage may visibly

*Fieldwork among Durrani Pashtuns of north-central Afghanistan was done jointly with Richard Tapper in 1970-72 as a Social Science Research Council (UK) project; for further information see $R$. and $N$. Tapper (1972) and $N$. Tapper $(1977,1979,1980$, and 1981). The ethnographic present refers to the fieldwork period. Detailed material was collected on only one subtribe; however, many aspects of its culture are comm on to Durrani throughout Afghan Turkistan, and I am reasonably sure that much of what I have to say is also applicable to the social organization of rural Durrani communities elsewhere in the country. 
confirm or indeed increase a household's poverty. However, it is crucial to an understanding of the system to realize that these same elements may also communicate the wealth and high status of a household and indeed increase that household's standing in the community. Through the choice of spouse, the character and amount of the prestations, and the manipulation of ritual symbols, marriage arrangements communicate the real and potential strengths and weaknesses of a household. Evaluations of a household's overall status within the community are made according to its marriage arrangements. While the marriages made by a wealthy household may confirm its strength, they may also reveal weaknesses of which others will take advantage. Furthermore, the complex of meanings associated with marriage arrangements directly affect women inasmuch as women identify themselves, and are almost totally identified with, their household of marriage. In more general terms, gender status as it is represented in relations between the sexes, as well as in relations among women or among men, depends on the way the institution of marriage as a whole is constituted: brideprice and the degree of independence of women are only two dimensions of this whole.

The members of the community discuss control of all resourcesespecially labor, land, and women-in terms of honor; debt and credit in all contexts, including marriage, are also assessed in these terms. We can view the real inequality in such a system as a spiral whereby the weak lose control of resources of all kinds, lose honor, and become weaker still, while the strong gain control of resources, gain honor, and become stronger. Yet honor, as it relates to inequality and competition, is balanced by an alternative Islamic and Pashtun ideology of equality, which is also seen in terms of honor.*

Elsewhere (N. Tapper 1981) I have analyzed Durrani marriage in terms of symmetrical and asymmetrical modes. The first, comprised of direct exchange marriage (primarily sister-exchange), conforms to Durrani egalitarian ideals and defines the ethnic group as a whole; the second, in which women are given for brideprice or in compensation for blood, creates and maintains a status hierarchy among Durrani households. Actors manipulate the ambiguities in each of these alternative modes to make and evaluate status claims. In other

"For a more detailed discussion of this point, see N. Tapper (1979:215ff., and 1981:391-93). 
words, both equality and competition are confirmed or denied through the complex institution of marriage and expressed in the language of honor.

The meaning of any Durrani marriage relates ultimately to the exchange system as a whole and to the differential values given to four ranked spheres of exchange (see Firth 1950 and Bohannan 1967). Men are ranked in the first and highest sphere. Direct exchanges between or of them include the most honorable and manly of all activities, and these activities are prime expressions of status equality: vengeance and feud (badi), political support and hospitality (milmastya), and the practice of sanctuary (nanawatay).

Women belong to the second sphere. Durrani women are often treated exclusively as reproducers and pawns in economic and political exchanges. Women accept this ranking of themselves, but they and men see their importance confirmed in the highly valued form of exchange marriage, the most important kind of exchange and a prime expression of status equality within this sphere.

Exchanges of productive resources-especially of land, animals, and valuables-form a third sphere, in which the equivalence of various items has more to do with the social relations between givers and receivers than with market values. The special treatment accorded productive resources and capital goods is perhaps best seen in the composition of a brideprice where, for example, the relation between the value of animals given and their market price is complicated and more indicative of social status than the prices of meat, milk, or wool in the bazaar. Exchanges of land and valuables are also treated in a special way and carry various complex meanings. It is of the greatest importance to Durrani that land should never be sold or mortgaged to outsiders. Similarly the loan or gift of expensive animals such as horses and camels and luxury goods such as guns, rugs, or jewelry is used as a gesture of political support or friendship between households. Land and other valuables are acceptable for inclusion in a brideprice, and the valuables included in a bride's trousseau should not be traded in the local market.

Finally, market values are relevant in direct exchanges of produce in the fourth sphere. The barter of produce is a frequent but low-status activity associated with the poor.

There is only one proper conversion between the first two spheres two or more women can be given in compensation for the 
killing or injury of one man. The meaning of this conversion is ambiguous, but usually the honor goes to the killers who have "taken" a man and "give" only two women. Marriage for brideprice is the most obvious form of conversion between the second and third spheres: a woman for productive resources, valuables, and cash. The conversion clearly compromises the honor of the wife-givers, who are very unwilling to take goods from the even lower sphere of produce (e.g., by accepting grain as a substitute for some part of the productive resources or capital goods of the brideprice), while honor redounds to the wife-takers. Such conversions communicate status inequality.

As noted, within the system debt does not result directly from brideprice payments, nor does wealth depend directly on being able to give women and receive productive resources. Rather it is the control (or lack of it) of the complex interactions among resources in all four spheres which leads to wealth (or poverty)-especially to a family's ability to cope with debts which arise in the wider social environment from dealings with the government, tribal leaders, or moneylenders. However they arise, debts to such external agents are greatly feared and can lead to the loss of women in marriage or the loss of male labor through imprisonment, voluntary exile, or the wholesale emigration of families from the region. Mortgages, especially of land or guns for cash or grain, are seen as a short-term strategy to finance such debts and to maintain household self-sufficiency-to stave off hunger and ensure the continued support of the male labor force. However, should such a short-term strategy fail, the household is likely to be left without male labor for production and defense and to be greatly weakened. An alternative and longer-term strategy to cope with the exigencies of the wider environment lies in marriage. Marriage arrangements can be delayed or exchanges arranged; men of any household can find brides and need not incur further debt to do so. Through immediate affinal support, and ultimately through sons, a household can continue to be self-sufficient.

In sum, brideprice is not simply a means to get a wife, such that its abolition would mean anyone is now free to find a wife. For the poor or disabled man there have always been alternative ways of getting wives, while brideprice has always involved a highly complex system of meanings beyond that of simple monetary value. The evidence of the ideology and practice of Durrani marriage has clearly shown that it is a system which encompasses the contradictory values 
of hierarchy and equality in Durrani society. Marriage provides the context and the motive for the expression of these values - and it does so not only among Durrani, but also between Durrani and other groups in the polyethnic state of Afghanistan. Viewed diachronically, the status and ethnic identity of both individuals and groups may change over time. For example, marriages may be used to achieve and simultaneously confirm Durrani identity and thus provide an effective means of incorporating non-Durrani in to the ethnic group. The opposite pattern is also found: ultimately individuals and groups who intermarry with other ethnic groups can lose Durrani status, especially when oppressed and impoverished households leave an area and migrate to a distant part of the country.

\section{ETHINICITY AND MARRIAGE}

The evidence presented above suggests that legislative tinkering with marriage prestations, even if fully implemented, could not in any simple way reduce indebtedness or improve the status of women among Durrani; rather it would overturn the whole social construction of marriage and its relation with other aspects of the social order. Moreover, I have hinted at some of the concomitant ethnic implications of Durrani marriage. In this section is a more detailed description of the relations among ethnic groups in northern Afghanistan based on marriage (see also N. Tapper and R. Tapper 1982).

Durrani ethnic identity and their ideals of status equality depend on claims to religiously privileged descent, implying superiority to all other ethnic groups. Much interethnic competition is disguised by Durrani perception of this superiority and by the absolute prohibition on the marriage of Durrani women to men who are not Durrani but are of some "lower" ethnic status. The integrity of the entire Durrani ethnic group depends on the maintenance of this rule, and breaches are dealt with collectively and with great ferocity.

The emphasis on descent and the ban on women marrying "down" (hypogamy) are also found among other groups of Pashtospeakers whom the Durrani loosely call Farsiwans - that is, groups of diverse origins such as Khalili and Maliki from southwest Afghanistan, Ghilzai, and other Eastern Pashtuns (see R. Tapper in this volume). Durrani consider these other Pashto-speakers to pose the greatest 
threat to their ethnic integrity and security. A relationship of rivalry and hostility between Durrani and Farsiwans is of long standing, and the Durrani ban on women marrying "down" with Farsiwans is an effective means of preventing Farsiwans from gaining access to Durrani resources and identity.

Durrani attitudes and values are different from those of all the non-Pashto speaking ethnic groups in the area. Persian-speaking groups such as Aymaqs, Arabs, Tajiks, and Hazarahs and Turkicspeaking Uzbeks and Turkmens are differentiated from the Durrani by basic features of social organization as well as language, custom, and (in the case of the Hazarahs) religion. The ethnic boundary with such groups is marked for the Durrani by a plethora of criteria, among which the ban on hypogamy, while it remains fundamental from the Durrani point of view, is simply taken for granted. Indeed it is made more or less irrelevant in this context by the other groups' own conceptions of both ethnic identity and marriage. Among the other ethnic groups in the area, there are various criteria of identity; in some cases they are based on economic differences, in other cases on geographical distribution, and so on. However, apart from the Arabs and Turkmen, institutions of descent and marriage do not seem to play a central role in marking ethnic boundaries as they do for the Durrani and Farsiwans.

In the system I have described for the Durrani, the overriding jural responsibilities for the control of a married woman (and the honor she represents) rest with her husband and his agnates. The virtually complete transfer of rights in and duties toward women at marriage is associated with a number of customary features: marriage is very expensive, there is no divorce, affinal ties are relatively unimportant, and women do not in practice inherit property (see N. Tapper 1979:29ff.). As far as I could ascertain, the marriage arrangements are different among the other ethnic groups: a woman is not completely alienated on marriage from her family of birth. She commonly takes her share of the patrimony, and her agnates retain residual rights in her-for example, in her remarriage as a widow. Moreover, marriage does not have the same relation to the control of productive resources and capital for these groups as it does for Durrani (and Farsiwans), and brideprices are usually considerably lower, both absolutely and in relation to wealth. Finally, and perhaps as a consequence of the character of marriage among these other 
ethnic groups, marriage is apparently not used among them, as it is among the Durrani, as the single most important means of political competition.

In addition to the factors discussed, there are other aspects of the relation between ethnicity and marriage which need consideration. For one thing, there is some intermarriage between all the groups I have mentioned. Indeed there is a network of intermarriage which liniss all the major ethnic groups in the area, as well as groups farther afield. Thus 10-15 percent of wives of men in the Durrani group were from "inferior" ethnic groups. Among the non-Durrani groups in the north-central part of the country, intermarriage may again account for perhaps 10-15 percent of all marriages. In both cases, a number of these marriage may lead to enduring political and economic ties between the households concerned. Certainly such a network of intermarriage has economic implications, not least in terms of marriage prestations per se.

Unfortunately there is not sufficient information available to elucidate the relation between the economics of brideprice and the movement of women throughout the country, though a countrywide pattern undoubtedly exists. I heard, for instance, that Durrani from Maymana travelled to Sistan to find inexpensive brides; others from the northwest went to Badakhshan for the same reason, while Durrani from the south of Afghanistan would travel north to marry their daughters where brideprices were high. Of course the monetary value of a brideprice is not the only consideration, and the implications of networks of intermarriage must be qualified in certain fundamental ways. The economic implications must be separated first from the motivation for such marriages and second from the meaning such marriages have in terms of ethnicity. As we have seen, at the very least intermarriage has a profound connection for Durrani, Farsiwans, Arabs, and Turkmens with ethnic identity per se, which in turn relates in a very basic way to conceptions of status differences within such ethnic groups. Though relations among marriage, the control of resources and information, and social status are different for other ethnic groups in the region, I think it is fair to assume, if only because of the economic and political power of the Durrani and Turikmen within the region, that any substantial alteration in the meaning of marriage within these,groups (perhaps by the implementation of marriage reforms) could lead to a complete restructuring of ethnic relations. 


\section{CONCLUSIONS}

Marriage reforms such as Decree No. 7 attack symptoms, not conditions of a social order. Nonetheless, they may have many snortferm consequences. For example, Beattie has described how marriage $n$ drangements in progress were simply halted by the decree's prohibition of marriage payments (p. 191 above; see also Olesen 1982:117n, $128,138 n$ ). Moreover, women suffer a diminution of value in their own eyes and those of their husbands and brothers by being given away "free" (see N. Tapper 1981). Such reactions occur in terms of the traditional system and are often expressed in terms of formal Islam. If the prohibition on brideprice payments and other expenses of marriage continues to be enforced in the absence of other fundamental changes, one can expect that the rraditional function of the institution of marriage in effecting and communicating status changes within a community will be repiaced by an altemative systern. Such a system, which would probably emerge as a variant on the traditional institutions, would aimost certainly continue to use the idiom of honor to express the control of productive and reproductive resources. Social inequality would persist, probably on the same scale as in traditional Afghan society, but would be revealed and manipulated by other means.

In the longer term, however, the underiying goals of the reforms-to reduce material indebtedness throughout the country and to ensure women's rights-could be approached oniy through the introduction of both an alternative motivation for production and a consistent program of education and other measures which would allow women to gain control of a variety of resources, including information, capital, and their own labor. But given that the marriage reforms are themselves derived by an Afghan eite from a First World ideology of production and gender roles, it is unlikely that these goals will be realized even if linked with substantial reforms in other areas. Rather, given the comparative scarcity of resources within the country, it is more likely that any such transformations of Afghan society would result in an inferior imitation of First World society in which poverty and discrimination against women remain integrally connected. 